\title{
Desmoplastic melanoma associated with an intraepidermal lentiginous lesion: case report and literature review*
}

\author{
Melanoma desmoplásico associado a lesão lentiginosa intraepidérmica, \\ com evolução de 10 anos: relato de caso e revisão bibliográfica
}

Cesar de Souza Bastos Junior ${ }^{1}$

Juan Manuel Piñeiro-Maceira²

Fernando Manuel Belles de Moraes $^{3}$

\begin{abstract}
Desmoplastic melanoma tends to present as firm, amelanotic papules. Microscopically, it reveals a proliferation of fusiform cells in the dermis and variable collagen deposition, as well as intraepidermal melanocytic proliferation of lentiginous type in most cases. Biopsy in a 61-year-old white male patient, who had received a diagnosis of lentigo maligna on his face 10 years before, revealed a proliferation of dermal pigmented spindle cells and collagen deposition, reaching the deep reticular dermis, with a lentiginous component. Immunohistochemistry with S-100, Melan-A and WT1 showed positivity, but it was weak with HMB45. Desmoplastic melanoma associated with lentigo maligna was diagnosed. Several authors discuss whether desmoplastic melanoma represents a progression from the lentiginous component or arises "de novo". Desmoplastic melanoma represents a minority of cases of primary cutaneous melanoma (less than $4 \%$ ). Identification of lentigo maligna indicates that desmoplastic melanoma should be carefully investigated.
\end{abstract}

Keywords: Melanoma; Nevus, epithelioid and spindle cell; S100 Proteins; WT1 Protein

Resumo: Os melanomas desmoplásicos apresentam-se como pápulas amelanóticas firmes; à microscopia exibem proliferação de células fusiformes na derme e variável deposição de colágeno, além de proliferação melanocítica lentiginosa, intraepidérmica, na maioria dos casos. Realizada biópsia de pele de paciente masculino, 61 anos, branco, com diagnóstico de lentigo maligno na face, há 10 anos. O exame histopatológico revela proliferação dérmica de células fusiformes pigmentadas e deposição de colágeno, invadindo até a profundidade da derme reticular, associado a componente lentiginoso; presença de positividade imuno-histoquímica com S-100, Melan-A e WT1, e marcação fraca com HMB45. Diagnóstico de melanoma desmoplásico, associado a lentigo maligno. Existe divergência quanto à origem do melanoma desmoplásico, a partir do componente lentiginoso ou "de novo", na ausência de lentigo associado. O melanoma desmoplásico representa uma minoria dos casos de melanoma cutâneo primário (menos de $4 \%$ ). A presença de lentigo maligno pode servir de sinal de alerta para possível relação com melanoma desmoplásico.

Palavras-chave: Melanoma; Nevo de células epitelióides e fusiformes; Proteínas S100; Proteínas WT1t

Received on 15.04.2012.

Approved by the Advisory Board and accepted for publication on 27.06.2012.

* Study conducted at the Federal University of Rio de Janeiro (UFRJ), Rio de Janeiro (Rio de Janeiro), Brazil.

Conflict of interest: None

Financial funding: None

Brazilian Society of Pathology, Specialist Certification. Master's degree in Pathology, Federal University of Rio de Janeiro (UFRJ). Pathologist at Hospital Naval Marcílio Dias (HNMD) - Rio de Janeiro (RJ), Brazil.

Armed Forces Institute of Pathology-Washington, D.C.-USA, PhD. Adjunct Professor at the Pathology Department, Federal University of Rio de Janeiro (UFRJ), Rio de Janeiro (Rio de Janeiro), Brazil.

Medical Residence at the Pathology Departament, Federal University of Rio de Janeiro (UFRJ), Pathologist at Hospital Naval Marcílio Dias (HNMD) - Rio de Janeiro (RJ), Brazil.

(C)2013 by Anais Brasileiros de Dermatologia 


\section{INTRODUCTION}

Melanomas are malignant neoplasms originated from melanocytes, neural crest-derived cells, which produce melanin from L-Tyrosine. These tumors can occur in several sites, especially the skin, and show classic patterns, such as superficial spreading melanoma, lentigo maligna melanoma, nodular melanoma and acral lentiginous melanoma, or rare variants such as desmoplastic melanoma (DM). This variant was originally described in 1971 by Conley et al. and often presents as a true diagnostic and therapeutic challenge to both dermatologists and dermatopathologists. ${ }^{1,2}$

DM is characterized by an amelanotic firm papule in sun exposed skin, notably in the head and neck region of elderly patients. ${ }^{3}$ Therefore, it can be clinically misdiagnosed as basal cell carcinoma, scar, dermatofibroma, nevus or cyst. In a recently published series, there was no clinical suspicion of melanoma in up to $2 / 3$ of affected patients. ${ }^{4}$

Histopathology reveals a spindle cell proliferation in the dermis with variable collagen deposition (desmoplasia). A storiform or spiral-like pattern can be seen. Neoplastic cells are often non-pigmented and show mild to severe atypia. Neurotropism is common. Therefore, the histological pattern may be wrongly taken by dermatopathologists as that of sclerosing blue nevus, atypical fibroxanthoma, leiomyosarcoma and many other sarcomas. ${ }^{5}$ As this variant can infiltrate the deepest parts of the skin, it may be difficult to determine its thickness, especially in less celullar lesions.

Although the classic clinical description of DM is that of a non-pigmented lesion, most DM lesions are histologically associated with an intraepidermal melanocytic proliferation, notably of lentiginous type (lentigo maligna). ${ }^{1}$ This has led some authors to assume that at least some DMs arise from a pre-existing melanoma in situ. However, a significant number of cases, 19 to $27 \%$ in some series, has no intraepidermal component. ${ }^{5,6}$

In $95 \%$ of the cases, immunohistochemistry shows positivity cases for S100 protein, vimentin, and neuron-specific enolase. ${ }^{7}$ Staining with HMB-45 and Melan-A is negative in most cases. Several studies have shown varying degrees of positivity with other markers such as NKI/C3, MITF, CD34 and bFGF. A recent study by Wilsher and Cheerala has shown immunoreactivity for WT-1 (an antibody against Willms tumor cells, a renal cancer characteristic of childhood) diffusely in the melanoma cells of a series of $11 \mathrm{DM}$, without any marking on neural cells, thereby contributing to a better identification of the infiltration pattern. ${ }^{8}$
Despite the great scientific advances in the field of tumoral investigative dermatology and dermatopathology, the association between two neoplasms of the same lineage, which may represent a "continuum" of evolution, can only be interpreted as an intriguing relationship.

\section{HISTOPATHOLOGIC DATA}

White male patient, sixty-one years old, retired, native of Portugal, married, seen in the Plastic Surgery Section, with a histopathological 10-year diagnosis of lentigo maligna, treated with surgical excision. Dermatological examination showed a large asymmetric pigmented lesion on his face, with irregular borders, different colors and a central enlarged nodular area, firm and with an infiltrative appearance (Figure 1). Dermathoscopy was highly suggestive of melanoma and biopsy was recommended. Histological sections showed a dermal proliferation of pigmented spindle cells with mild nuclear atypia and coarse collagen deposition, with deep invasion of the reticular dermis. There was, concurrently, an atypical intraepidermal melanocytic lentiginous proliferation above the dermal lesion, but without continuity (Figures 2 and 3). Immunohistochemistry revealed positivity in both dermal and epidermal components for S-100, Melan-A and WT1. Immunostaining with HMB45 was also present in the epidermal melanoma cells, but the staining of the dermal component was only focal and weak (Figures 4, 5 and 6). The diagnosis was desmoplastic melanoma associated with intraepidermal atypical melanocytic proliferation of lentigo maligna type. The indicated treatment was surgical excision, with mid-frontal flap in the nasal dorsum, skin graft on the corner of the eye (donor area: left eyelid) and lateral advancement flap in both eyelids. There have been no signs of clinical relapse so far.

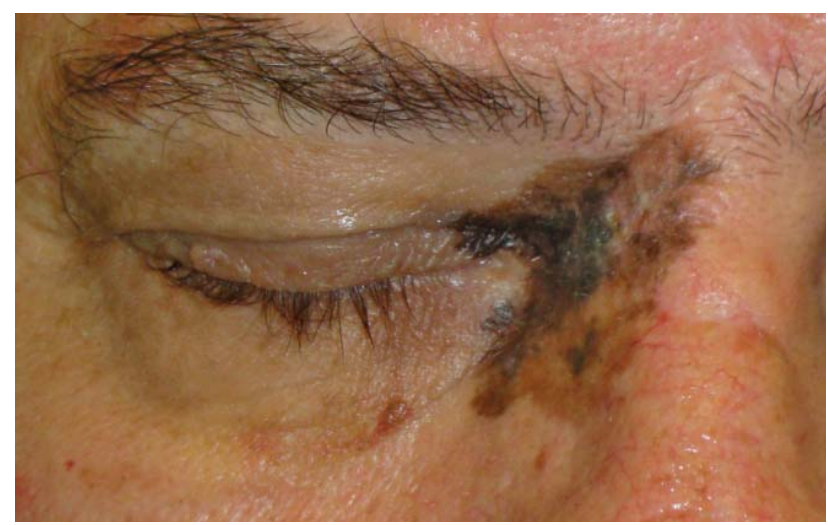

FIGURE 1: Melanocytic lesion, located on the corner of the right eye, featuring an irregular surface 


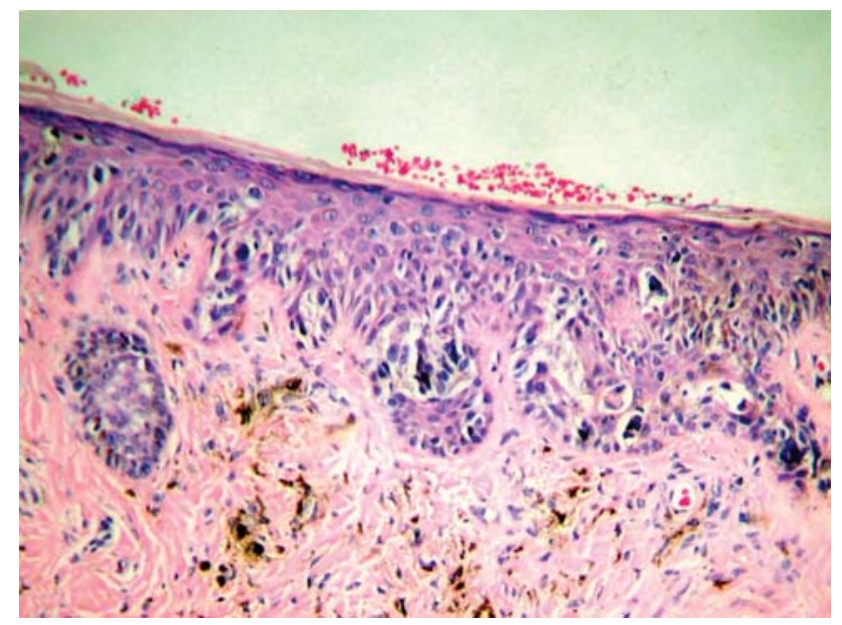

FIGURE 2: Intraepidermic component of lentigo maligna melanoma. Haematoxylin Eosin \&-200 X

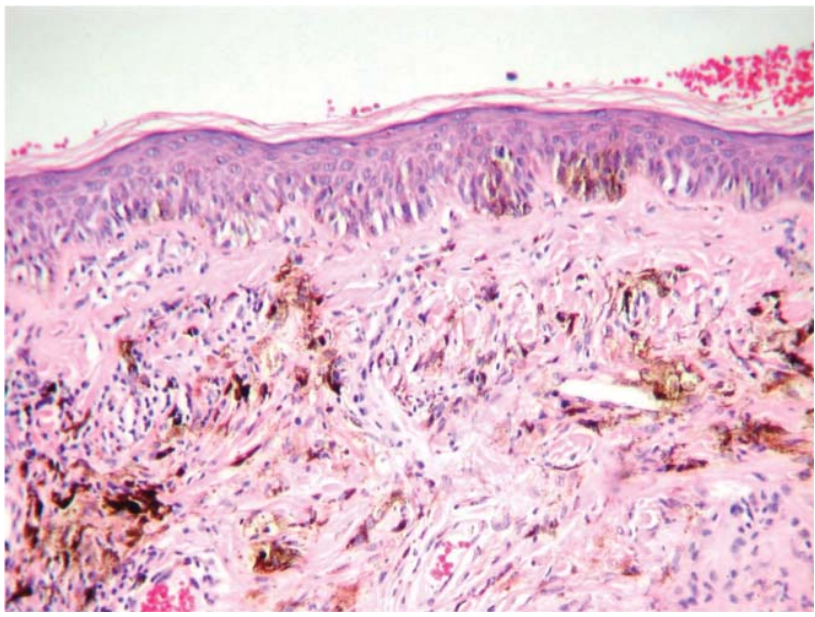

FIgURE 3: Dermal melanocytes, with a moderate amount of pigment. Haematoxylin \& Eosin - 100 X

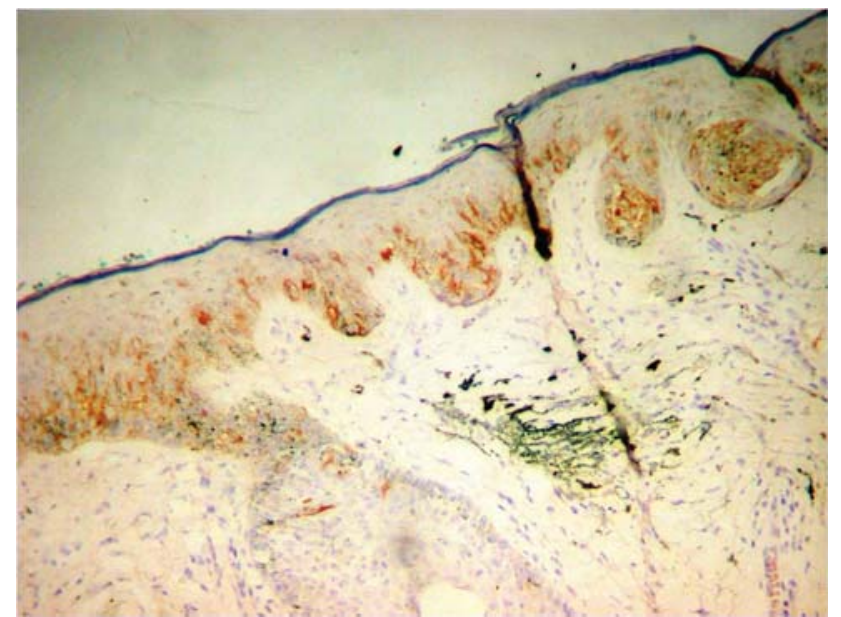

FIGURE 4: Intraepidermic positivity of HMB-45. Negativity in dermis $-100 \mathrm{X}$

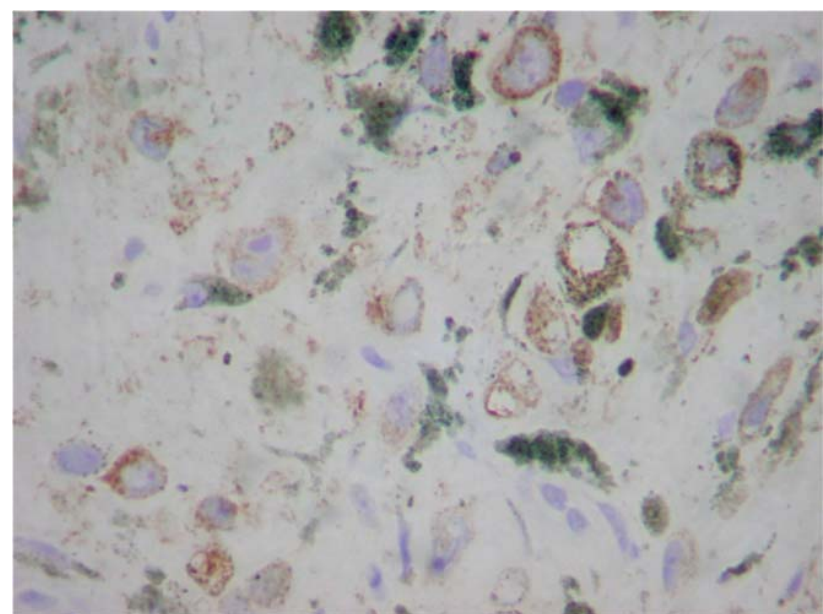

FIGURE 5: Immunopositivity for WT-1 in dermal melanocytes $-400 X$

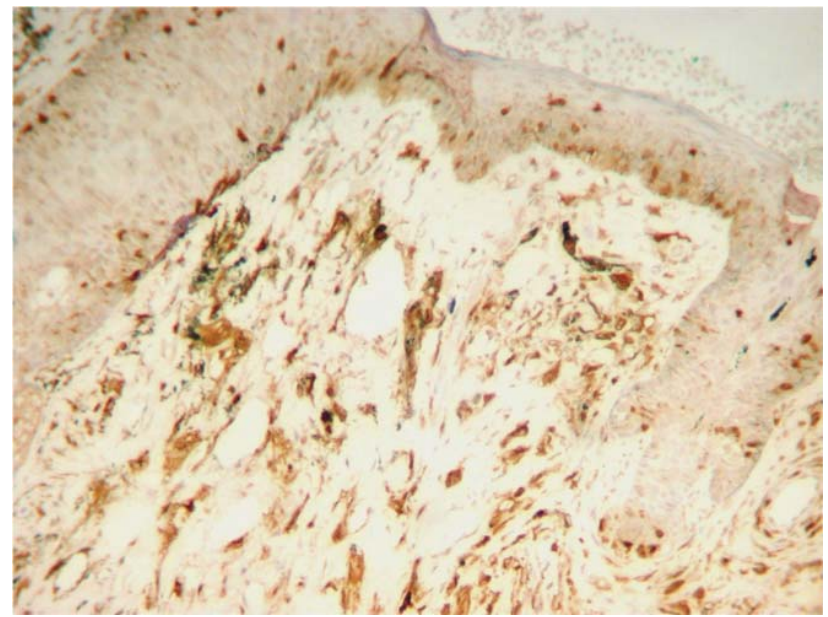

FIGURE 6: S100 Immunopositivity in dermal melanocytes - $200 \mathrm{X}$

\section{DISCUSSION}

Desmoplastic melanoma represents a minority $(4 \%)$ of cutaneous melanomas. ${ }^{5,6}$ However, a recent study has shown that it is highly represented in malpractice claims related to melanoma. ${ }^{9}$ This fact could be explained by its clinical-pathologic peculiarities.

Its clinical appearance is usually that of an inconspicuous discoid papule, plaque or nodule. Pigmentation is infrequent and most lesions are amelanotic or hipomelanotic, which leads to misdiagnosis. ${ }^{10}$ However, an adjacent pigmented area similar to lentigo maligna is not unusual, as we saw in the case described above. ${ }^{11}$

Current literature shows a predilection for the head and neck. However, the largest series ever published shows that this preference is not so evident ${ }^{11}$.

Dermatoscopy, a useful tool that helps dermatologists to identify suspicious pigmented lesions, is 
not routinely performed in the case of these tumors, since their appearance is usually amelanotic. Therefore, dermatoscopic findings of desmoplastic melanomas were only described in 2008, in a series of six cases. ${ }^{4}$ Only half of these cases were identified as melanocytic lesions according to dermatoscopic criteria. The authors suggest that in the absence of such criteria, attention should be given to findings suggestive of regression and to the vascular pattern associated with melanoma. ${ }^{10}$

Weedon et al. reported that desmoplastic melanomas usually have a lentigo maligna component in the epidermis overlying the lesion or in resection margins, similar to what was seen in the case reported. ${ }^{12}$

Mihm et al defined desmoplastic melanoma as "a form of melanoma in vertical growth phase in which the invasive tumor cells have a spindle morphology and are associated with marked stromal response" ${ }^{13}$ Furthermore, they reported the association of lentigo maligna in the epidermis and considered that this subtype of melanoma in fact corresponds to two types of lesions: true desmoplastic melanomas and spindle cell melanomas, both sharing several morphological characteristics. To them, this last group of lesions corresponds to the most common pattern of vertical invasion in lentigo maligna melanoma.

Carlson et al. also observed the presence of an atypical intraepidermal melanocytic proliferation in up to $85 \%$ of desmoplastic melanomas, $56 \%$ of which could be considered a lentigo maligna. ${ }^{3}$ In this series of 28 melanomas, 12 were pigmented and were clinically considered to be lentigens, congenital nevi or dermatofibromas. Most lesions were located on the face and neck. Fifteen percent of the cases in this series did not have any intraepidermal melanocytic component and were called "de novo", assuming that they had arisen spontaneously in the dermis or there had been regression of the epidermal component. In some of these cases, regression features can be recognized in histopathology. In this study, only a minority of the desmoplastic melanomas showed continuity between dermal and epidermal components, and these were significantly thinner than the melanomas that had a collagen-free zone between the two components ("Grenz Zone"). Moreover, the amount and extent of the intraepidermal melanocytic component appear to decrease in thicker lesions. In the study of Carlson et al., 9 of 10 tumors had an adjacent lentigo maligna component and 9 of 12, who had a "Grenz Zone", showed only a slightly prominent atypical melanocytic proliferation; only one had lentigo maligna exclu- sively. ${ }^{3}$

Likewise, Anstey et al demonstrated in their series of 25 cases a dermal papillary transitional component, which was different from both deep dermal spindle cells and the overlying intraepidermal tumor. ${ }^{14}$ This might suggest an intermediate evolutionary phase between these two components.

Egbert, Sagebiel et al. describe 24 cases of desmoplastic melanomas with a lentigo maligna component in the epidermis and one showing only atypical melanocytic proliferation in their report of 25 desmoplastic melanomas. ${ }^{15}$ In their article, they mention an earlier study that classified desmoplastic melanoma as being associated with lentigo maligna, without an epidermal component (de novo) or associated with minimal deviation melanoma. According to these authors, desmoplastic melanomas and spindle cell melanomas represent a "continuum" of lesions with a similar morphology, and the diagnosis of desmoplastic melanomas should be reserved for lesions that meet all criteria for desmoplastic melanomas, except for the presence of an epidermal component, which is frequent but not present in all cases. Spindle cell lesions without a significant desmoplastic stromal response are more accurately called spindle cell melanomas.

Elenitsas et al. showed an unusual positivity for Melan-A in three of 43 desmoplastic melanomas. ${ }^{16}$ These authors also believe that most desmoplastic melanomas are variants of lentigo maligna melanoma, based mainly on the high frequency of lesions on sun damaged skin, in the head and neck region, in elderly patients, and because the junctional component of most desmoplastic melanomas is indistinguishable from lentigo maligna. Moreover, there seems to be a morphological continuity between desmoplastic melanoma and invasive spindle cell melanoma. However, desmoplastic melanoma is more aggressive than lentigo maligna melanoma because it has a higher tendency to extend deeply into the dermis and metastasizes more frequently than other types of melanoma occurring on sun exposed skin.

\section{CONCLUSION}

Currently, the consensus is that the lentiginous component in desmoplastic melanoma is a frequent but not essential condition for diagnosis. Different authors consider two possibilities for the origin of desmoplastic melanoma, also called by some as spin-

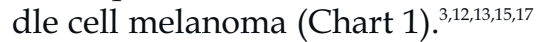


CHART 1: Opinions about the meaning of the lentiginous component in desmoplastic melanoma

\begin{tabular}{|c|c|c|c|}
\hline Authors subject & Presence of intraepidermal component & Hmb-45 staining & Nature of injury \\
\hline WEEDON et al..$^{12}$ & Yes, Lentigo Maligna type (LM). & $\begin{array}{l}\text { Stains intraepidermal component, } \\
\text { and in up to } 20 \% \text { of cases stains } \\
\text { dermal melanocytes. }\end{array}$ & Not mentioned. \\
\hline MIHM et al. ${ }^{13}$ & Yes, Lentigo Maligna type (LM). & $\begin{array}{l}\text { Stains dermal melanocytes in } \\
\text { up to } 20 \% \text { of cases. }\end{array}$ & $\begin{array}{l}\text { Arised from LM } \\
\text { or "de novo" }\end{array}$ \\
\hline $\begin{array}{l}\text { SKELTON, MACEIRA } \\
\text { et al. }{ }^{17}\end{array}$ & $\begin{array}{l}\text { Cases with epidermal component } \\
\text { without specifying the type. }\end{array}$ & $\begin{array}{l}\text { Dermal staining in up to } 50 \% \text { of cases } \\
\text { (with worst biological behavior). }\end{array}$ & Not mentioned. \\
\hline CARLSON et al. ${ }^{3}$ & $\begin{array}{l}\text { Yes, LM type, or atypical melanocytic } \\
\text { proliferation (AMP), or superficial } \\
\text { spreading melanoma (rarely) }\end{array}$ & $\begin{array}{l}\text { Dermal component staining in up } \\
\text { to } 21 \% \text { of the cases. }\end{array}$ & $\begin{array}{l}\text { Arised from LM } \\
\text { or "de novo" }\end{array}$ \\
\hline $\begin{array}{l}\text { EGBERT, SAGEBIEL } \\
\text { et al. }{ }^{15}\end{array}$ & Yes, LM ( $95 \%$ of cases) and AMP & Not mentioned. & $\begin{array}{l}\text { Arised from LM } \\
\text { or "de novo" }\end{array}$ \\
\hline
\end{tabular}

- a - DM with an atypical lentiginous proliferation as a precursor lesion;

- b - DM arising "de novo" from dermal melanocytes, with the association or not of an atypical intraepidermal lentiginous component.

The real nature of this component and its meaning in the context of spindle cell melanoma have yet to be clarified.

\section{REFERENCES}

1. Conley J, Lattes R, Orr W. Desmoplastic malignant melanoma (a rare variant of spindle cell melanoma). Cancer. 1971;28:914-36.

2. DiCaudo DJ, McCalmont TH, Wick MR. Selected diagnostic problems in neoplastic dermatopathology. Arch Pathol Lab Med. 2007:131:434-9.

3. Carlson JA, Dickersin GR, Sober AJ, Barnhill RL. Desmoplastic neurotropic melanoma. A clinicopathologic analysis of 28 cases. Cancer. 1995;75:478-94.

4. Debarbieux S, Ronger-Salve S, Dalle S, Balme B,Balme L. Dermoscopy of desmoplastic melanoma: report of six cases. Br J Dermatol. 2008:159:360-3.

5. Busam KJ. Cutaneous desmoplastic melanoma. Adv Anat Pathol. 2005;12:92-102.

6. de Almeida LS, Requena L, Rütten A, Kutzner H, Garbe C, Pestana D, et al. Desmoplastic malignant melanoma. A clinicopathologic analysis of 113 cases. Am J Dermatopathol. 2008;30:207-15.

7. Quinn MJ, Crotty KA, Thompson JF, Coates AS, O'Brien CJ, McCarthy WH. Desmoplastic and desmoplastic neurotropic melanoma: experience with 280 patients. Cancer. 1998;83:1128-35.

8. Wilsher M, Cheerala B. WT1 as a complementary marker of malignant melanoma: an immunohistochemical study of whole sections. Histopathology. 2007:51:605-10.

9. Troxel DB. Pitfalls in the diagnosis of malignant melanoma: findings of a risk management panel study. Am J Surg Pathol. 2003:27:1278-83

10. Manganoni AM, Farisoglio C, Bassissi S, Braga D, Facchetti F, Ungari M, et al. Desmoplastic melanoma: report of 5 cases. Dermatol Res Pract. 2009;3:22-27.

11. Payne WG, Kearney R, Wells K, Blue M, Walusimbi M, Mosiello G, et al. Desmoplastic melanoma. Am Surg. 2001;67:1004-6.

12. Weedon D. Skin pathology. 2th ed. London: Churchill Livingstone; 2002. p.710-4.

13. Magro C, Crowson M, Crowson A, Mihm Jr MC. Unusual variants of malignant melanoma. Mod Pathol. 2006;19:S41-S70.

14. Anstey A, McKee P, Jones EW. Desmoplastic malignant melanoma: a clinic patho- logical study of 25 cases. Br J Dermatol. 1993:129:359 -71.

15. Egbert B, Kempson R, Sagiebel R. Desmoplastic malignant melanoma. A clinicohistopathologic study of 25 Cases. Cancer. 1998:62:2033-41.

16. Elenitsas R, Kucher C, Zhang PJ, Pasha T. Expression of Melan-A and Ki-67 in Desmoplastic Melanoma and Desmoplastic Nevi. Am J Dermatopathol . 2004:26:452 - 457.

17. Skelton, Henry G.; Maceira, Juan ; Smith, Kathleen J. ; McCarthy, William F. ; Lupton, George P.; Graham, James, et al. HMB45 Negative Spindle Cell Malignant Melanoma. Am J Dermatopathol. 1997;19:580-4.

How to cite this article: Bastos-Junior CS, Piñeiro-Maceira JM, Moraes FMB. Desmoplastic melanoma associated with an intraepidermal lentiginous lesion: case report and literature review. An Bras Dermatol. 2013;88(3):408-12.

MAILING ADDRESS:

Cesar de Souza Bastos Junior

Av. Brigadeiro Trompowsky s/n - Ilha do Fundão

21941-590 - Rio de Janeiro - RJ

Brazil

E-mail:cesar.548@gmail.com 